\title{
Automatic Question Generation With Classification Based On Mind Map
}

\author{
Selvia Ferdiana Kusuma \\ Informatics Department \\ Institut Teknologi Sepuluh \\ Nopember \\ Surabaya, Indonesia \\ selvia1805@mhs.its.ac.id
}

\author{
Daniel Oranova Siahaan \\ Informatics Department \\ Institut Teknologi Sepuluh \\ Nopember \\ Surabaya, Indonesia \\ daniel@its.ac.id
}

\author{
Chastine Fatichah \\ Informatics Department \\ Institut Teknologi Sepuluh \\ Nopember \\ Surabaya, Indonesia \\ chastine@its.ac.id
}

\author{
Mohammad Farid Naufal \\ Informatics Department \\ Universitas Surabaya \\ Surabaya, Indonesia \\ faridnaufal@staff.ubaya.ac.id
}

\begin{abstract}
In Indonesia's national education system, a question within a national standardized school examination (Ujian Sekolah Berstandar Nasional, USBN) is generated based on a predetermined grid. A predetermined grid is a matrix that contains a set of criteria that all question should abide. Students who would like to take the final school exam usually prepare themselves by learning through the existing predetermined grid then extend their knowledge around the predetermined grid. But extending knowledge around the predetermined grid is not easy because it depends on the student's creativity to associate the material that exists. The contribution of this research is to generate various types of questions that have relevance to the predetermined grid. The dataset that used is learning the material of all grade in 4, 5, and 6 of elementary school science subjects. The question generation process is done by the rule which generated from the mind map. The mind map will help to determine the interrelationship between the learning material. This study uses 50 competencies from the predetermined grid as input to generate questions. The results of question generation are then validated by an expert. Expert state that all inputs used can generate questions according to competence. The experiment result shows that the proposed method can be used to generate questions that are related to the predetermined grid.
\end{abstract}

Keywords-Question Generation, Rule-Based, Mind Map, Question Classification

\section{INTRODUCTION}

In Indonesia, the questions for the final exam are developed through a predetermined grid [1]. A predetermined grid is a matrix that contains a set of criteria that all question should abide. The purpose of making a predetermined grid is to determine the scope and as instructions for writing questions [2]. The predetermined grid consists of competency, material scope, material, cognitive level, question indicator, the form of a question, and a number of the question [3]. Formal education in Indonesia consists of elementary school, junior high school, senior high school, and university. An elementary school has six levels. Start from grade 1 until grade 6 . Students in the sixth grade of elementary school should pass a national standardized school examination (Ujian Sekolah Berstandar Nasional, USBN) to be able to continue to the junior high school level. Questions of USBN for elementary schools in Indonesia are a combination of learning material in grades 4, 5, and 6 . Therefore, to passed USBN, students are required to remember and also linking their knowledge from learning the material in grades 4,5 , and 6 . Students who will face USBN usually learn through the predetermined grid provided by their teacher. Then they extend the predetermined grid to predict other questions that might come out on USBN. But, to predict other questions is not easy. Students must understand the learning material then they can make questions about that.

Currently, the questions in USBN have several difficulty levels. Questions with varying difficulty level can be used to assess students' abilities more precisely [4]. The varying difficulty level is divided into three levels, namely Lower Order Thinking Skill (LOTS), Medium Order Thinking Skill (MOTS), and High Order Thinking Skill (HOTS). The first level is LOTS. LOTS means the students can remember and understand a learning material. For example, a LOTS question is "What is perfect metamorphosis?". This question is considered as having LOTS level because to answer it, a student needs to understand the learning material about perfect metamorphosis. The second level is MOTS. MOTS means the students can applicate a learning material. For example, a MOTS question is "Animals classified as perfect metamorphosis are...". This question is considered as having the MOTS level because to answer it, a student needs to apply their knowledge to classify animals that carry out perfect metamorphosis. The third level is the HOTS. HOTS mean students have reasoning abilities for learning material. For example, a HOTS question is, "Are there factors that influence perfect metamorphosis? Try to explain your opinion!". This question is considered as having the HOTS level because to answer it, a student needs to provide an analysis of what factors will affect the perfect metamorphosis process [5]. HOTS questions are usually made from a combination of previous learning material. Therefore students are also required to understand the interrelationships between learning material.

Latipah and Adman [6] using a mind map to improve learning outcomes. Mind map could help students to find out the important points of discussion in the learning material [7]. There has been no other study where mind map combines similar materials from different levels of grades. Recently, mind maps are only made for each chapter or subchapter. It will only help students to understand the points one by one, but not the interrelationship, and the question that may arise from the learning material. Currently, mind maps are just learning media. Although there is a possibility that mind maps can also be used to help make learning evaluation questions automatically. 
Recently, there have been several studies using both Indonesian and English that try to generate questions automatically. The research included the question generation of $5 \mathrm{~W} 1 \mathrm{H}$ for the domain of Indonesian using syntactical templated-based features from academic textbooks [8], generating automatic type questions for Indonesian texts that use compound sentences [9], and generating questions in Indonesian based on Bloom's Taxonomy using template-based methods [10]. There are also three studies related to the question generation that use English, namely automatic/smart question generation system for the academic purpose [11], automatic question generation from paragraph [12], and automatic generation-based questions on analysis of sentence structure [13]. The majority of research that has been carried out only focuses on generating questions according to the sentences or paragraphs that are used as input. The question raised is dependent on the input sentence. There is still rarely research that can generate questions outside the input sentence but still have relevance to the sentence used as input.

The variety of types of questions commonly used for evaluating learning outcomes requires that automation of question generation in the field of education can generate questions with the varying difficulty level. To generate questions with varying difficulty level cannot only depend on input sentences but also must understand the relevance of the input sentences with the other topics. Therefore this study focuses on generating questions outside of input sentences but having relevance to sentences that are used as input. This study uses a mind map to see the interrelationships between topics. The existence of a mind map helped to increase the variety of questions.

This paper is organized as follows. In section 2, we have described the previous work. In section 3, we have introduced the implementation of our approach. In section 4, we have evaluated the result. In section 5, we have described the conclusions of this method and future work.

\section{PREVIOUS WORK}

Setio \& Kusuma [8] made the generation of questions for the academic field. Four processes are carried out to generate these questions including the identification of declarative sentences for eight co-classes and 19 fine-class sentences, the classification of rules for fine-class sentences, the identification of question patterns and the extraction of sentence components as well as the rule generation of questions. This research resulted in an accuracy of $83 \%$ for coarse class and $92 \%$ for fine class.

Ginanjar and Purnamasari [9] make automatic question generation for Indonesian Texts containing compound sentences. The method consists of two stages, namely preprocessing and main processing. Pre-processing is the initial stage for getting word types and entities named for each word in the sentence, while the main process is a syntactic analysis process which consists of identifying phrases with pattern matching methods, the process of determining grammatical functions with rule-based methods and the question generation process with the template-based method. The results of the problem generation accuracy are $71.06 \%$.
Kusuma and Alhamri [10] make the question generation classified according to the taxonomy of bloom. The method used is template based. This research does not only generate questions but also classifies the level of difficulty. The classification process is based on the keywords that appear on the question. In addition to questions, this study also predicts answers based on the template that has been made. But the question generation in this study is very dependent on the sentence inputted. This study cannot generate questions outside the inputted sentence.

Vibahndik and Samant [11] made the generation of questions in the field of Education. There are seven stages used to generate a question. The seven stages are Key Phrase Extraction, Key Phrase Classification Conceptual Graph Construction and Conceptual Question Generation, Abbreviation Extraction, Possible Option Extraction, and MCQ generation. This research only focuses on five categories of education, namely Research Field, Technology, System, Term, and others.

Swali, Palan, and Shah [12] do the generation of questions from a paragraph using a semantic approach and a syntactic approach. Each sentence will be selected first, whether it can be a question or not. The selection process is done by identifying the features of each sentence. The features used are the first sentence, last sentence, frequently appearing words, sentence length, number of nouns, adverbs, and conjunctions. This study has not been able to make questions from sentences that have pronouns.

Blstak \& Viera [13] performs the question generation through the template-based method obtained from sentence structure analysis. This study produces a more effective pattern than previous studies because it has fewer patterns but has better results in generating problems. The pattern in this study was made through a combination of POS Tags, Named Entity Relations (NER), and Super Sense Tags (SST). Although it has good accuracy, the use of combining patterns makes the computing process more complex.

\section{RESEARCH METHODOLOGY}

In this section, we have described our approach in detail. There are three processes in this study, namely dataset collection, mind map building, and question generation and classification.

\section{A. Dataset Collection}

The dataset used is elementary schools science learning materials of class 4,5 , and 6 . The material is obtained from the Buku Sekolah Elektronik (BSE) of the Indonesian Ministry of Education. The material has been used as a material for making mind maps.

\section{B. Mind Map Building}

Mind maps are built based on discussion points in a material. Figure 1 shows an example of a mind map of the animal life cycle. 


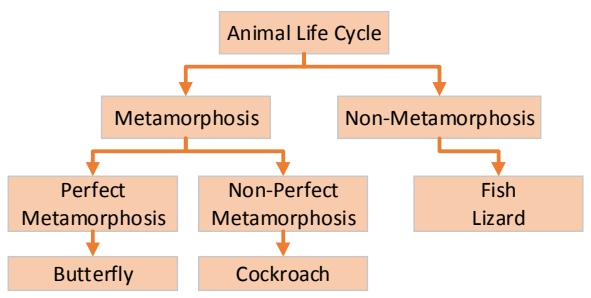

Figure 1. Mind Map of Animal Life Cycle

From the main discussion point, the mind map of the animal life cycle will branch out into smaller sub-discussions. There are no specific rules or limitations in making mind maps. Therefore, one mind map can have various versions. The majority of mind maps do not bring up issues that can be used as questions from the material. Therefore, the mind map used in this study was modified. It focuses on generating mind maps to generate a question based on the material. The mind map in this study would also be modified so that it has material relevance in the previous class. An example of an extended mind map used as a dataset is shown in Figure 2.

Mind maps are formed from a collection of discussion points, grade, sub-discussion points, and issues. Fourth components come from learning material at BSE. Discussion point comes from the material in BSE. The grade comes from the level in elementary school. The sub-point discussion comes from the sub-material discussed, while the issue is formed from the questions that appear in the final evaluation section in the material/discussion point. Each discussion point is related to sub-discussion points. Linkages can occur between subdiscussion point in one class or different classes $(4.5$, or 6$)$. The sub-discussion point grouping is important because sometimes there is a connection between sub-discussion point that we must know, for example before understanding breeding in animals, students should know about the theory of animal life cycle processes, animal classification and other theories related to animal life. Experts will validate the truth of the formation of discussion points, sub-discussion points, issues, and grouping of discussion points. Examples of discussion point are "2. Hewan" (2. Animal). Example of grades is 4,5 or 6. Example for the sub-discussion is "2.1Penggolongan hewan" (2.1 Animal Classification). The example for the issue of the sub-discussion is in point "2.1.1Terdiri dari" (2.1.1 consists of). The issue was formed because, at the end of the evaluation, there was a question "Classification of animals consisting of ...".

The extended mind map concept in Figure 2 looks almost the same as ontology-based knowledge modeling as in the research of Le Thanh, Matokhina, and Kizim [14] who use ontology to model knowledge in the domain of "Electrical Engineering." But actually, ontology is not suitable if applied in this study. The concept of ontology is to provide relationships between each class using the property. In this study, knowledge is divided into four parts, namely discussion points, grades, discussion sub-points, and issues. Subdiscussion points always have issues that represent questions that can be raised from the sub-discussion. The issue does not explain the relationship between sub-discussions. So, the concept cannot be equated with ontology

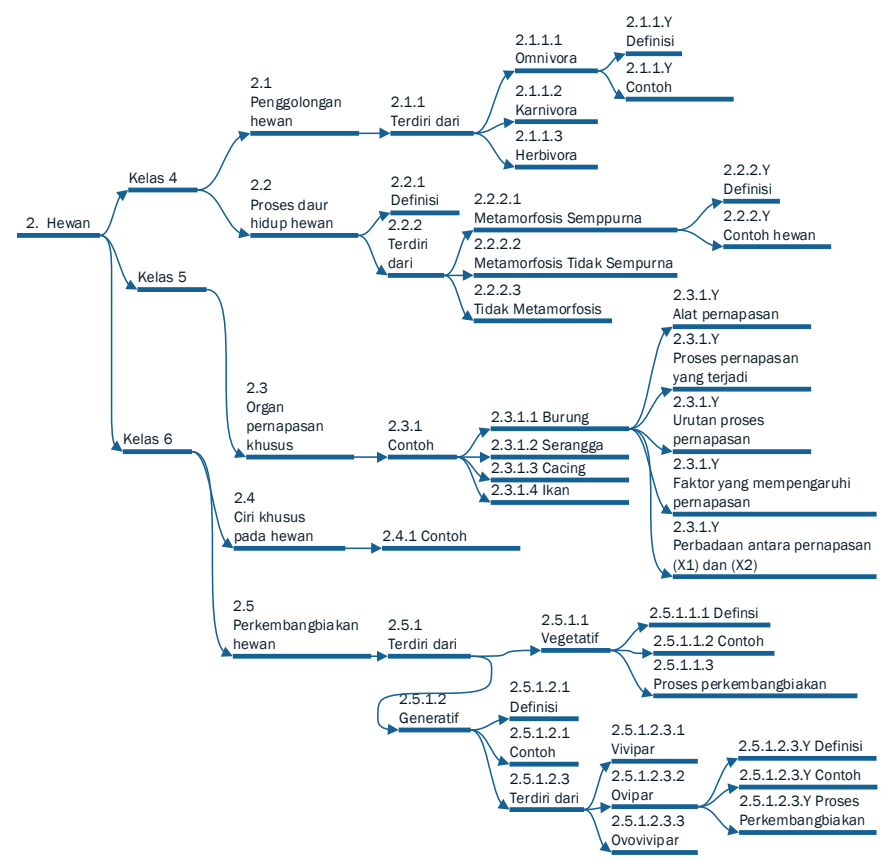

Figure 2. Extended Mind Map of Animal (Hewan)

After there are sub-points of discussion there will be an issue related to the sub-points of the discussion and so on. The issue "2.1.1Terdiri dari" (consisting of) will produce the next sub-discussion point, which is divided into omnivores, carnivores, herbivores. From the second sub-discussion point, new issues will arise regarding "2.1.1.1Y Definisi" (2.1.1.Y Definitions) and "2.1.1.Y Contoh hewan" (2.1.1.Y An example of an animal).

The process of making mind maps is shown in Figure 3. The process is done manually by an expert in the field of education. The expert will collect material along with supporting questions from each material for grades 4,5 , and 6 . Then the expert will raise the issue of each material based on the questions that are often raised from the material. The issues that arise will be formed like a mind map. Rule generation questions will be developed based on the mind map that is formed. Examples of rule from mind maps in Figure 2 are shown in Table 1. Rules that are made are general, which means they can be applied to any material. For example, for the issue of "2.3.1.Y Proses yang terjadi pada (X)" (The process that occurs in $(\mathrm{X})$ ), the issue can be used to generate questions from material about "2.3.1.1 Burung" (Bird) and "2.3.1.3 Ikan" (Fish). The example of the question is, "How do the process that occurs in Bird breathing?" And "How to do the processes that occur in Fish breathing?". The symbol (X) is the sub-discussion point from the previous branch. The symbol (Y) in each issue means that the issue can be used to generate questions from sub-discussion points in the previous branch. Besides generating rules, experts will also determine the difficulty level of the questions in every rule. Classification on the difficulty level is based on Bloom's Taxonomy. Capability for remembering $(\mathrm{C} 1)$ and understanding $(\mathrm{C} 2)$ are classified into LOTS level. Capability for applying (C3) is classified into MOTS level. While Capability for analyzing (C4), evaluating 
TABLE I. RULE IDENTIFICATION

\begin{tabular}{|c|c|l|l|l|}
\hline No & Level & \multicolumn{1}{|c|}{ Issues } & \multicolumn{1}{|c|}{ Rule } & \multicolumn{1}{c|}{ Generated Questions } \\
\hline 1 & $\mathrm{~L}$ & $\begin{array}{l}2.1 .1 \text { Terdiri dari.. } \\
\text { (Consist of) }\end{array}$ & $\begin{array}{l}\text { (X) terdiri dari... } \\
(\text { X) Consist of..) }\end{array}$ & $\begin{array}{l}\text { Questions 1:Penggolongan hewan terdiri dari... (Animal classification consists of...) } \\
\text { Questions 2:Perkembangbiakan hewan terdiri dari...(Animal breeding consists of...) }\end{array}$ \\
\hline 2 & $\mathrm{H}$ & $\begin{array}{l}2.3 .1 . Y \text { Proses yang } \\
\text { terjadi } \\
\text { (Processed Occurred) }\end{array}$ & $\begin{array}{l}\text { Bagaimana proses yang } \\
\text { terjadi pada (X)? } \\
\text { (How is the process that } \\
\text { occurs at (X)?) }\end{array}$ & $\begin{array}{l}\text { Question 1: Bagaimana proses yang terjadi pada pernapasan burung? (How is the process } \\
\text { that occurs at bird breathing?) } \\
\text { Question 2: Bagaimana proses yang terjadi pada pernapasan ikan?(How is the process } \\
\text { that occurs at Fish breathing?) }\end{array}$ \\
\hline 3 & $\mathrm{H}$ & $\begin{array}{l}\text { Hubungan antar } \\
\text { materi pelajaran. } \\
\text { (Linkages between } \\
\text { materials) }\end{array}$ & $\begin{array}{l}\text { Apakah ada hubungan } \\
\text { antara (X) dan (W)? } \\
\text { (Is there a link between (X) } \\
\text { and (W)?) }\end{array}$ & $\begin{array}{l}\text { Question 1: Apakah ada hubungan proses daur hidup hewan dan perkembangbiakan } \\
\text { hewan? (Is there a link between animal life cycle and breeding of animals?) } \\
\text { Question 2: Apakah ada hubungan antara organ pernapasan dan ciri khusus pada } \\
\text { hewan? (Is there a link between respiratory organs and special characteristics in animals?) }\end{array}$ \\
\hline
\end{tabular}

(C5), and creating (C6) are classified into the HOTS level [2]. The difficulty level for each rule will be shown in the level column. L means LOTS, $\mathrm{M}$ means MOTS, and $\mathrm{H}$ means HOTS. There is an issue that is not directly reflected as a branch of sub-discussion point, for example, in table 1 no 3 . The issue of the relationship between materials appears not yet reflected as a branch because this issue will always be generated automatically from 2 sub-discussion point.

\section{Question Generation and Classification}

The concept of the question generation process from beginning to end is shown in Figure 3. The generation of questions begins by entering the competency as input. Then the competency is entered into the preprocessing, which consists of tokenizing process, stop word removal, and lemmatization. The term from preprocessing result will be compared with the words in the mind map. When there are the same words, mark the sub-discussion points. Then find the suitability of the issue based on the selected sub-discussion points. Use the rule in each issue that is selected to generate questions. The results of this method are questions that have different difficulty level but still have a relationship of discussion with the competency used as input.

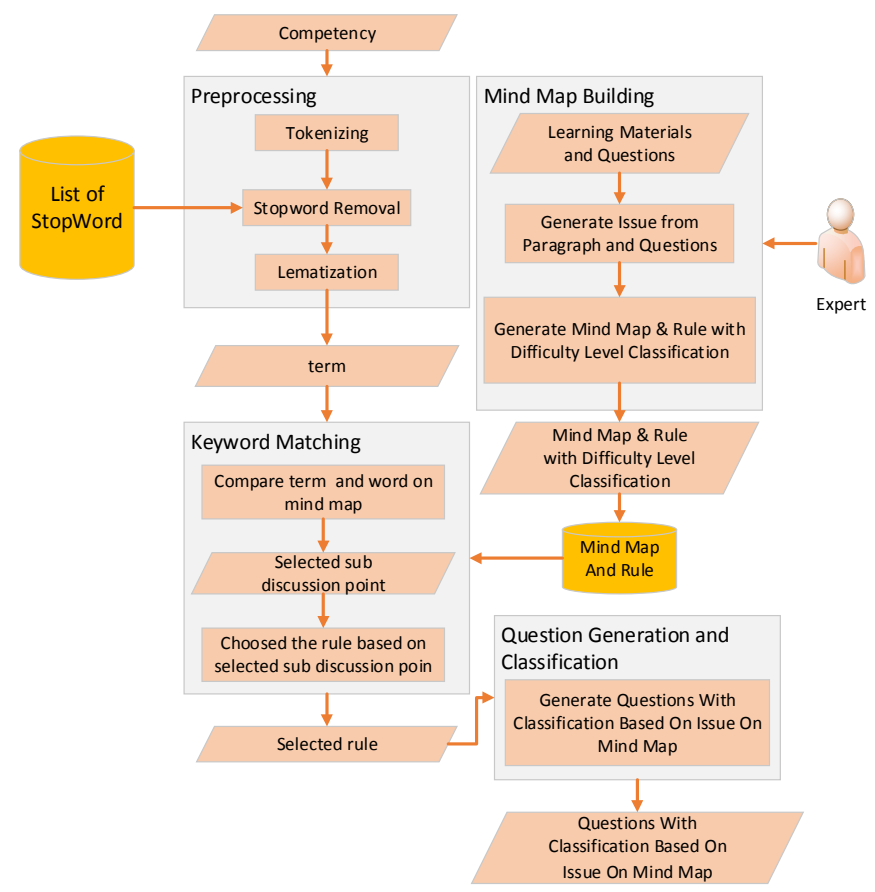

Figure 3. Question Generation Process
The difficulty level for each question raised has been determined during the process of making mind maps and rules for each issue on the mind map. Details of each process shown in Figure 3 will be explained in the following sections.

\section{Preprocessing}

The input in this study is a competency. Competency is one part of the predetermined grid. An example of competency is "Siswa dapat menjelaskan tentang proses pernapasan pada burung" (Students can explain the breathing process in a bird). In accordance with the steps in Figure 3, the input then goes to the preprocessing stage. Preprocessing begins with tokenization, stop word removal, and stemming. Tokenization is the separation of sentences into word to word. The results of the tokenizing process are "Siswa-dapat-menjelaskan-tentangproses-pernapasan-pada-burung." After tokenizing then going to the stop word removal process. Stop word removal is used to remove non-essential words. The non-essential words referred to in this study are words that do not represent related topics in this discussion point. The result after the stop word removal is "proses-pernapasan-burung." The word "siswa" (student) is not included in the stop word, but the words are added to the stop word because the word is considered meaningless in this study. The next step is the lemmatization process. Lemmatization means getting the basic word from a word. The result of lemmatization process is "proses-napas-burung." The results of the lemmatization process are the terms that will be used as input in the process of keywords matching.

\section{Keyword Matching}

Keyword matching is done to find the appropriate discussion points and rules on the mind map. Two processes occur at the keyword matching stage. First is comparing the terms and words in the mind map to determine sub-discussion points, and the second is rule selection based on the selected sub-discussion points. These rules will be used as a benchmark for generating questions. In the first process, each input in the keyword matching process will be matched with a discussion point from the leftmost mind map. When the word is not found in each discussion point, then searches for the second branch of each sub-discussion point (marked with 2-digit number code) and so on. But if the word is found, it will focus only on the appropriate sub-discussion point. For example, the keywords used are "proses-napas-burung" (process-breath-bird). The words are found in code 2.3 for "breath", 2.3.1.1 for "bird" and 2.3.1.Y, 2.5.1.1.3, 2.5.1.2.3.Y for "process". 
TABLE II. RULE OF QUESTION GENERATION

\begin{tabular}{|c|c|l|l|}
\hline No & Level & \multicolumn{1}{|c|}{$\begin{array}{c}\text { Issues } \\
(\mathbf{2 . 3 . 1 . Y )}\end{array}$} & \multicolumn{1}{c|}{ Rule } \\
\hline 1 & L & $\begin{array}{l}\text { Alat pernapasan } \\
\text { (Respiratory) }\end{array}$ & $\begin{array}{l}\text { (X) bernapas dengan... } \\
\text { (X) breathe with...) }\end{array}$ \\
\hline 2 & L & $\begin{array}{l}\text { Proses pernapasan yang } \\
\text { terjadi } \\
\text { (The breathing process } \\
\text { that occurs) }\end{array}$ & $\begin{array}{l}\text { Proses yang terjadi pada } \\
\text { pernapasan (X) adalah... } \\
\text { (Process which is happened (X) } \\
\text { is...) }\end{array}$ \\
\hline 3 & M & $\begin{array}{l}\text { Urutan proses } \\
\text { pernapasan } \\
\text { (Sequence of breathing } \\
\text { process) }\end{array}$ & $\begin{array}{l}\text { Urutan proses penapasan (X) } \\
\text { adalah... } \\
\text { (Sequence of breathing process on } \\
\text { (X) is...) }\end{array}$ \\
\hline 4 & H & $\begin{array}{l}\text { Faktor yang } \\
\text { mempengaruhi proses } \\
\text { pernapasan } \\
\text { (Factor that effects on } \\
\text { breathing process) }\end{array}$ & $\begin{array}{l}\text { Faktor yang mempengaruhi proses } \\
\text { pernapasan (X) adalah... } \\
\text { (Factor that effect on breathing } \\
\text { process (X) is...) }\end{array}$ \\
\hline 5 & H & $\begin{array}{l}\text { Perbedaan antara dua } \\
\text { proses pernapasan } \\
\text { (The difference } \\
\text { between 2 breathing } \\
\text { process) }\end{array}$ & $\begin{array}{l}\text { Perbedaan antara pernapasan (X1) } \\
\text { dan (X2) adalah... } \\
\text { (The difference between the } \\
\text { breathing of (X1) and (X2) is ...) }\end{array}$ \\
\hline
\end{tabular}

The word "process" is located in more than 1 subdiscussion point. If there are words detected in some subdiscussion point, the word will be ignored. That makes the focus of the sub-discussion point for generating questions, not false. After getting the sub-discussion points then proceed to the second process, namely rule selection based on the selected sub-discussion points. Every sub discussion point always has an issue. The issue is always after the sub discussion point. Every issue has a rule, so the rule will be found if an issue has been found - the example rule used in this study, as shown in table 2. The (X) represents a sub-discussion point in the previous branch. If there are two sub-discussion point compared, then codes X1 to Xn will be used.

\section{Question Generation and Classification Process}

The generation of questions is based on the rule that appears. Examples of questions that can be generated from the rule in Table 2 are shown in Figure 4. If the rule "(X) breathe with..." then the symbol (X) will be replaced with the previous sub-discussion point. In this case, the sub-discussion point is a bird. So the question that will be formed is "Bird breathes with...". From point 2.3 about respiratory organs, it is known that respiratory organs material in animals not only discusses the respiratory of bird but also discusses the respiratory of insect, worms, and fish. So, the rules that were used to generate questions related to respiratory of bird can also be used to raise questions regarding the respiratory of insect, worms, and fish. The results of the generation of questions for respiratory of bird in animals are shown in Figure 4. Sub-discussion about the respiratory organ of animal has produced 20 questions. But the example in Figure 4 only produces five questions because it only raises questions for 1 type of animals, namely bird. The same rule can be used to generate questions for similar subdiscussion point at the same level.

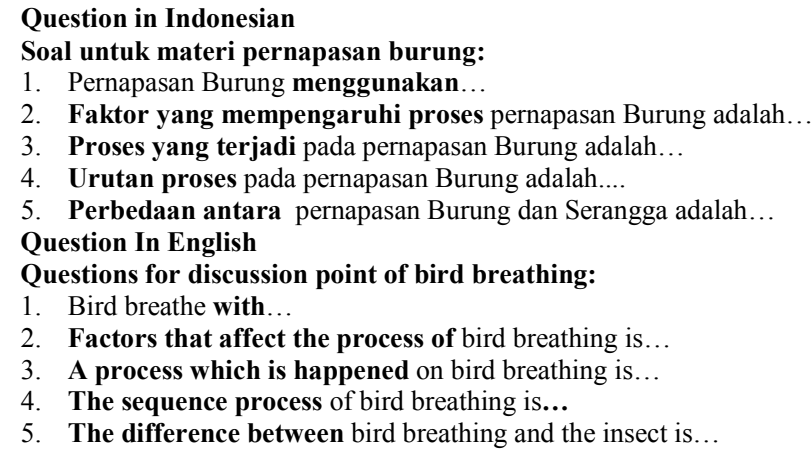

Figure 4. Result of Question Generation and Classification

The generated rule is equipped with the difficulty level. So that when using the rule, it will be known what level the question is. Question number 1 in Figure 4 is the question of remember level (LOTS) because to answer it, students have to remember the material that has been studied. Question number 4 is a question of apply level (MOTS) because to answer it, the student has applied theory about respiratory of a bird. Number 3 is the question of understanding level (LOTS) because to answer questions, students only should explain the understanding. Whereas questions number 2 and 5 are a question of analyzing level (HOTS) because the answers to these questions are not in the material being studied. So, the student must analyze by their self. The division of the difficulty level of this question is based on Bloom's Taxonomy.

\section{RESULT AND DISCUSSION}

From this study, it is known that to be able to generate a question at the HOTS level, it cannot be made simply by using descriptive sentences from a material. But also need to use the linkages of the information that is available to form HOTS questions. Therefore, to find out the interrelationship between learning materials, a mind map is needed. The mind map will help to see the relationship between words and learning materials. There are eight discussion points in the mind map that are used as datasets. There are human, animal, environment, objects, universe, energy, and force (Manusia, hewan, lingkungan, benda, alam semesta, energy, dan gaya). The eight discussion points produced 412 issues. Completeness of mind map will affect the number of issues. The more issue of the mind map, the more questions that can be generated. Figure 5 shows a comparison chart between the number of discussion sub-points and the number of issue of questions that can be raised. The majority of data shows that the generation of the issue is twice as large as the discussion point. The $\mathrm{X}$ axis on the chart represents the discussion point while the $\mathrm{Y}$ axis represents the number of issues from each discussion point. 


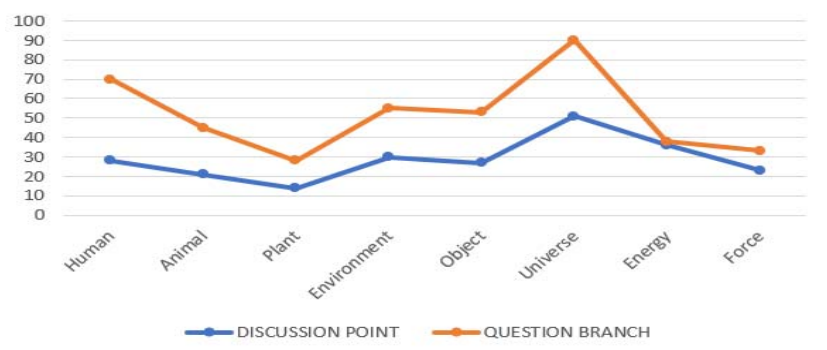

Figure 5. Comparison Between Discussion Points And Number of Issue

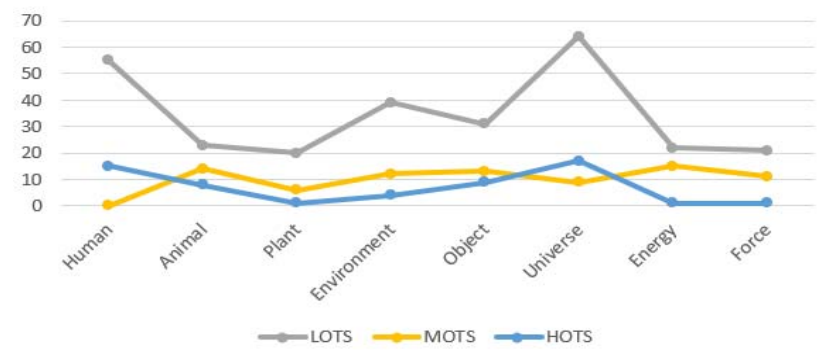

Figure 6. Comparison of The Number of Questions For Each Difficulty Level

Figure 6 shows a comparison chart between the number of questions that can be raised at each level. The $\mathrm{X}$-axis on the chart shows the discussion point while the Y-axis represents the number of questions at each difficulty level from each discussion points.

From these data, it can be seen that LOTS level produces the highest questions, and HOTS level produces the fewest questions compared to other levels. These happened because the rule of generating questions at HOTS level that has been successfully modeled is still limited. There must be another method used to generate questions at the HOTS level. The experiment in this study uses 50 competencies from the predetermined grid as input. And then competency produced questions similar to the competency. The result of question generation validated by an expert. Experts validate by comparing questions generated by experts with questions generated by this method. If it is the same, it will be marked "yes," but if not, it will be marked "no." The number of "yes" answers will be divided by the total number of questions raised. The calculation will represent the accuracy of the success of the proposed method. An expert who carries out validation of generated questions suggests that all of the questions are related to the competency used as input.

\section{CONCLUSION}

Mind maps will help determine the interrelationship between the learning material. Mind maps can be used to help generate questions automatically and with the various difficulty level. The more branch the mind map has the more questions that can be generated. There are 412 issues that can be used as material for generating questions. But from the 412 issues, only 56 issues were categorized at the HOTS level. From this study, it is known that the rules that have been modeled to generate
HOTS level questions are still limited. Therefore, there must be another method used to generate questions at the HOTS level. Besides that, the next research will also focus on developing a more varied and dynamic generate question method.

\section{ACKNOWLEDGMENT}

The authors say thank you to the Ministry of Research and Higher Education for supporting this research and all of the participants who have helped in the process of collecting datasets, classification, and validation in this research.

\section{REFERENCES}

[1] Hazraini, "Upaya Meningkatkan Kompetensi Guru Kelas Dalam Penyusunan Soal Pilihan Ganda Yang Baik dan Benar Melalui Pendampingan Berbasis KKG Semester Satu Tahun Pelajaran 2017/2018 di SD Negeri 40 Cakranegara," Jurnal Pendidikan Mandala, vol. 2, no. 2, pp. 111-121, 2017.

[2] H. Syofyan, "Penyuluhan dan Pelatihan Pendidikan Tentang Pembuatan Kisi-Kisi Soal untuk Guru-Guru di Yayasan Perguruan Birrul Waalidain Semplak Bogor," Jurnal Abdimas, vol. 3, no. 1, pp. 12-17, 2016.

[3] D. I. Rahardjo, "Bedah Kisi-Kisi USBN SD/MI Tahun 2018 Bagi Guru dan Kepala Sekolah," Widyaiswara LPMP Jawa Timur, Surabaya, 2018.

[4] S. F. Kusuma, D. Siahaan and U. L. Yuhana, "Automatic Indonesia's Questions Classification Based On Bloom's Taxonomy Using Natural Language Processing," in International Conference on Information Technology Systems and Innovation (ICITSI), Bandung, 2015.

[5] M. Z. Fanani, "Strategi Pengembangan Soal Higher Order Thinking Skill (HOTS) Dalam Kurikulum 2013," Edudeena, vol. 2, no. 1, p. 96, 2018.

[6] H. W. Latipah and Adman, "Penerapan Model Pembelajaran Mind Mapping Untuk Meningkatkan Hasil Belajar Peserta Didik," Jurnal Pendidikan Manajemen Perkantoran, vol. 1, no. 2, pp. 125-137, 2018.

[7] D. Safitri, "Penerapan Metode Mind Mapping Untuk Meningkatkan Minat Dan Hasil Belajar IPA Siswa Kelas V SDN Balangan 1," Jurnal Pendidikan Guru Sekolah Dasar, vol. 3, no. 5, pp. 193-203, 2016.

[8] S. Basuki and S. F. Kusuma, "Automatic Question generation For 5W$1 \mathrm{H}$ Open Domain Of Indonesian Questions By Using Syntactical Template-Based Features From Academic TextBooks," Journal Of Theoretical and Applied Information Technology, vol. 96, no. 12, pp. 3908-3923, 2018.

[9] D. D. Ginanjar and K. K. Purnamasari, "Pembangkitan Pertanyaan Otomatis Untuk Teks Berbahasa Indonesia yang Mengandung Kalimat Majemuk," pp. 1-7, 2016.

[10] S. F. Kusuma and R. Z. Alhamri, "Generating Indonesian Question Automatically Based On Bloom's Taxonomy Using Template Based Method," Kinetik, vol. 3, no. 2, pp. 145-152, 2018.

[11] D. S. Vibhandik and R. C. Samant, "Automatic / Smart Question Generation System for Academic Purpose," IJETTCS, vol. 4, no. 4, pp. 52-56, 2015.

[12] D. Swali, J. Palan and I. Shah, "Automatic Question Generation from Paragraph," International Journal of Advanced Engineering and Research Development, vol. 3, no. 12, pp. 73-75, 2016.

[13] M. Blastak and V. Rozinajova, "Automatic Question Generation Based On Analysis of Sentence Structure," Springer International Publishing, Switzerland, 2016.

[14] L. T. T. Nguyen, M. A. V. and K. A. V., "Creation and Use of Ontology of Subject Domain "Electrical Engineering," in International Conference on Application of Information and Communication Technologies (AICT), Rostov on Don, Russia, 2015. 
2019 16th International Joint Conference on Computer Science and Software Engineering (JCSSE 2019)

Chonburi, Thailand 10 - 12 July 2019 
Copyright (C) 2019 by the Institute of Electrical and Electronics Engineers, Inc. All Rights Reserved

Copyright and Reprint Permissions: Abstracting is permitted with credit to the source. Libraries are permitted to photocopy beyond the limit of U.S. copyright law for private use of patrons those articles in this volume that carry a code at the bottom of the first page, provided the per-copy fee indicated in the code is paid through Copyright Clearance Center, 222 Rosewood Drive, Danvers, MA 01923.

For other copying, reprint or republication permission, write to IEEE Copyrights Manager, IEEE Service Center, 445 Hoes Lane, Piscataway, NJ 08854. All rights reserved.

*** This is a print representation of what appears in the IEEE Digital Library. Some format issues inherent in the e-media version may also appear in this print version.

$\begin{array}{ll}\text { IEEE Catalog Number: } & \text { CFP1932P-POD } \\ \text { ISBN (Print-On-Demand): } & 978-1-7281-0720-2 \\ \text { ISBN (Online): } & 978-1-7281-0719-6 \\ \text { ISSN: } & 2372-1642\end{array}$

\section{Additional Copies of This Publication Are Available From:}

Curran Associates, Inc

57 Morehouse Lane

Red Hook, NY 12571 USA

Phone: (845) 758-0400

Fax: $\quad$ (845) 758-2633

E-mail:_curran@proceedings.com

Web: $\quad$ www.proceedings.com 


$\begin{array}{lll}\text { Keynote } & \text { Title } & \text { Page }\end{array}$

$\begin{array}{lll}\text { Keynote-I Business Transformation with Blockchain } & \text { XXIV }\end{array}$ by Professor Dr.Dusit Niyato

Keynote-II Matching Next-Gen HPC with Target Applications $\quad$ XXV by Professor Dr. Pascal Bouvry

$\begin{array}{lll}\text { Paper ID } & \text { Title Page }\end{array}$

1570538175 Hybrid EEG-fEMG based Human-Machine Interface for 1 Communication and Control Applications

by Kessarabhorn Chuysud and Yunyong Punsawad

1570547231 Circular Vector Field Analysis for the Adaptive Diffusion Flow Snakes Applied to Ultrasound Images of Breast Cancer

by Annupan Rodtook and Khwunta Kirimasthong

1570547324 A Linear-time Algorithm for Optimal Tree Completion

by Chawin Aiemvaravutigul and Nonthaphat Wongwattanakij

1570537927 Thai Handwriting Beautification

by Supawan Tasanaprasert and Karun Tonmaithong

1570528296 Discovering Factors Associated with Online Gaming Behaviors

by Bernardinus Harnadi

1570529455 Enhancing a Keyword Search Using Segmentation and Similarity Measure Algorithms : A Case Study of Phuket Attractions

by Kitsiri Chochiang and Witaya Khuanwilai

1570537320 ARCode: Augmented Reality Application for Learning Elementary Computer Programming

by Sirawit Sittiyuno and Kornchawal Chaipah 


\section{$\begin{array}{lll}\text { Paper ID } & \text { Title } & \text { Page }\end{array}$}

1570542545 Web-based Elderly Monitoring System with GIS 38

by Anirut Sriwichian, Veera Boonjing, Jirapond Muangprathub and Pichetwut Nillaor

1570542664 A Result Verification of Decision Tree Model for Industrial

Wireless Sensors Selection using Analytic Hierarchy Process

by Saksiri Meesawad, Bundit Thanasopon

and Olarn Wongwirat

1570542733 An Ontology for SNORT Rule

by Assadarat Khurat and Wudhichart Sawangphol

1570542789 An Information Integration System to Continuing of Care

Case study Nongsung Hospital, Mukdahan THAILAND

by Pranithan Klangprapunt and Pusadee Seresangtakul

1570542908 WhatTheHealth: An Android Application for Consumers of Healthy Food

by Songsri Tangsripairoj, Nonthpat Wongkham,

Bongkotmanee Leelalerkiat and Sarun Chuenpukdi

1570543015 Game Elements to Promote Walking in Thais Working Adults

by Sakchai Muangsrinoon and Poonpong Boonbrahm

1570543074 Condition Based Maintenance for Data Center Operations Management

by Montri Wiboonrat

1570547326 Practical Differential Privacy for Location Data Aggregation using a Hadamard Matrix

by Patinya Sangiamchit and Jittat Fakcharoenphol

1570542774 IVAA: Intelligent Vehicle Accident Analysis System

by Kundjanasith Thonglek, Norawit Urailertprasert,

Patchara Pattiyathanee and Chantana Chantrapornchai 


\section{$\begin{array}{lll}\text { Paper ID } & \text { Title } & \text { Page }\end{array}$}

1570542836 DATA++: An Automated Tool for Intelligent Data Augmenta- 91 tion Using Wikidata

by Waran Taveekarn, Chatchanin Yimudom, Supisara Sukkanta, Steven Lynden, Wudhichart Sawangphol and Suppawong Tuarob

1570542940 Multi-Paths Generation for Structural Rule Quests

by Thongtham Chongmesuk and Vishnu Kotrajaras

1570542954 Kiddy Manner: A Game-Based Mobile Application for

Children Learning Thai Social Etiquette

by Songsri Tangsripairoj, Mathawee Sukkhet, Jidapa Sumanotham and Benya Yusuk

1570543067 Speech-to-Thai Sign Language Conversion for Thai Deaf: A

by Nattapol Namyang, Jarukit Lumpaolertwilai and

Suphakant Phimoltares

1570543079 Semi-Automatic Word-Aligned Tool for Thai-Vietnamese Parallel Corpus Construction

by Dang Ngoc Chuong and Pusadee Seresangtakul

1570527283 Development of Reliable Wireless Communication System for Secure Blockchain-based Energy Trading

by Zhuoxian Huang, Kongrath Suankaewmanee, Jiawen Kang, Dusit Niyato and Pei Sin Ng

1570542701 An In-Memory Checkpoint-Restart Mechanism for a Cluster of Virtual Machines

by Jumpol Yaothanee and Kasidit Chanchio

1570542745 Moving Object Detection using Integrated Spatial and Motion-Based Method

by Manit Chansuparp and Kulsawasd Jitkajornwanich

1570543979 Estimating the new Initial Value of Trial Division Algorithm for Balanced Modulus to Decrease Computation Loops

by Kritsanapong Somsuk, Thanapat Chiawchanwattana and Chalida Sanemueang 


\section{$\begin{array}{lll}\text { Paper ID } & \text { Title } & \text { Page }\end{array}$}

1570546542 A DIFF-Based Indoor Positioning System Using Fingerprinting 142

Technique and K-Means Clustering Algorithm by Apichon Anuwatkun, Jirapat Sangthong and Sommart Sang-Ngern

1570547233 Enhanced DDoS Detection using Hybrid Genetic Algorithm 146 and Decision Tree for SDN

by Parinya Preamthaisong, Anucha Auyporntrakool,

Phet Aimtongkham, Titaya Sriwuttisap and Chakchai So-In

1570542673 The Control Model for Environmental Factor Effecting on by Narongsak Lekbangpong, Theera Srisawa, Apirat Wanichsombat and Jirapond Muangprathu

1570543106 A Low-Cost RTK GNSS Receiver with Cloud-Based Control Center Application by Duangduen Asavasuthirakul, Sittha Saisawan, Antony Harfield and Prasert Wiangsukphaiboon

1570528326 Development of Behavior Monitoring System for Honeybees in Hive Using RFID sensors and Image Processing by Shinya Takahashi, Koji Hashimoto, Sakashi Maeda, Yujie Li, Naoyuki Tsuruta and Hiroyuki Ai

1570536960 Analysis and Prediction of Temporal Twitter Popularity Using Dynamic Time Warping

by Rattasit Sermsai and Sirisup Laohakiat

1570537018 Text Generation for Imbalanced Text Classification

by Suphamongkol Akkaradamrongrat, Pornpimon Kachamas and Sukree Sinthupinyo

1570537322 Information Extraction based on Named Entity for Tourism

Corpus

by Chantana Chantrapornchai and Apisit Tunsakul

1570537371 Cross-Category Product Recommender System based on Multi-Criteria Rating using Diversity and Novelty Evaluation by Saranya Maneeroj, Pongsakorn Jirachanchaisiri, Chanisara Suksomjit and Apirom Zatloukal 


\section{$\begin{array}{lll}\text { Paper ID } & \text { Title Page }\end{array}$}

1570538865 Physically-Based Modelling and Simulation of Track-based

Main Battle Tank System for a realistic 3D Game

by Yodthong Rodkaew

1570539829 Vehicle Logo Detection Using Sliding Windows with Sobel Edge Features and Recognition Using SIFT Features

by Jatupon Benjaprakairat and Pakorn Watanachaturaporn

1570541149 Fake News Detection System using Article Abstraction

by Kyeong-hwan Kim and Chang-Seong Jeong

1570542302 An Individual Local Mean-based 2DPCA for Face Recognition under Illumination Effects

by Kangsadan Hancherngchai, Taravichet Titijaroonroj and Jaratsri Rungrattanaubol

1570542304 Modified Scale-Space Analysis in Frequency Domain Based on Adaptive Multiscale Gaussian Filter for Saliency Detection by Jenjira Jaemsiri, Taravichet Titijaroonroj and Jaratsri Rungrattanaubol

1570542305 Seven Segment Display Detection and Recognition usin

Pre-defined HSV Color Slicing Technique by Sorawee Popayorm, Taravichet Titijaroonroj, Thanathorn Phoka and Wansuree Massagram

1570542312 Quantitative Trading Machine Learning Using Differential by Napas Vinitnantharat, Narit Incha, Thatthai Sakkumjor, Kitsada Doungjitjaroen and Chukiat Worasucheep

1570542529 Ensemble CNN and MLP with Nurse Notes for Intensive Care Unit Mortality by Aye Hninn Khine, Wiphada Wettayaprasit and Jarunee Duangsuwan

1570542534 Convolutional Neural Networks Using MobileNet for Skin Lesion Classification

by Wannipa Sae-Lim, Wiphada Wettayaprasit and

Pattara Aiyarak 


\section{$\begin{array}{lll}\text { Paper ID } & \text { Title Page }\end{array}$}

1570542693 A Hotel Hybrid Recommendation Method based on Context- 242 Driven using Latent Dirichlet Allocation

by Weraphat Nimchaiyanan and Saranya Maneeroj

1570542719 Spatio-Temporal Deep Learning for Ocean Current Predic- 248 tion Based on HF Radar Data

by Nathachai Thongniran, Peerapon Vateekul, Kulsawasd Jitkajornwanich, Siam Lawawirojwong and Panu Srestasathiern

1570542737 Utilizing Google Translated Reviews from Google Maps in Sentiment Analysis for Phuket Tourist Attractions

by Boonyanit Mathayomchan and Kunwadee Sripanidkulchai

1570542740 Thai Sign Language Recognition Using 3D Convolutional Neural Networks

by Nutisa Sripairojthikoon and Jaturon Hansomboon

1570542979 Identifying an Original Copy of The Source Codes in Programming Assignments

by Chawalit Saoban and Sunisa Rimcharoen

1570543012 Classification of Nutrient Deficiency in Black Gram Using

Deep Convolutional Neural Networks

by Kadipa Aung Myo Han and Ukrit Watchareeruetai

1570543029 An Open-source Based Automatic Car Detection System using

IoT

by Assadarat Khurat, Nappaphol Siriphun,

Jiratchaya Saingthong and Jirapat Sriwiphasathit

1570543035 Natural Language Contents Evaluation System for Detecting

Fake News using Deep Learning

by Ye-chan Ahn and Chang-Sung Jeong

1570543077 A Hybrid Engine for Clinical Information Extraction from Radiology Reports

by Er. Khushbu Gupta, Ratchainant Thammasudjarit and

Ammarin Thakkinstian 


\begin{tabular}{|c|c|c|}
\hline Paper ID & Title & Page \\
\hline 1570543082 & $\begin{array}{l}\text { Classification of Anger Voice in Call Center Dialog } \\
\text { by Widakorn Saewong and Janjao Mongkolnavin }\end{array}$ & 292 \\
\hline 1570547230 & $\begin{array}{l}\text { Classification of Fruit In a Box (FIB) Using Hybridization of } \\
\text { Color and Texture Features } \\
\text { by Jirapat Watcharasing, Thanaporn Thiralertphanich, Sasipa } \\
\text { Panthuwadeethorn and Suphakant Phimoltares }\end{array}$ & 297 \\
\hline 1570547250 & $\begin{array}{l}\text { Graph Clustering with K-Nearest Neighbor Constraints } \\
\text { by Wararat Jakawat and Raywat Makkhongkaew }\end{array}$ & 303 \\
\hline 1570547316 & $\begin{array}{l}\text { Optimizing a Number of Overlapping Items for Eqauting Es- } \\
\text { timated Item Parameters } \\
\text { by Sarunya Deachnatee }\end{array}$ & 308 \\
\hline 1570547403 & $\begin{array}{l}\text { Region-Focus Training: Boosting Accuracy for Deep- } \\
\text { Learning Image Segmentation } \\
\text { by Chanok Pathompatai, Ratchadaporn Kanawong and } \\
\text { Pinyo Taeprasartsit }\end{array}$ & 313 \\
\hline 1570542506 & $\begin{array}{l}\text { An Image-Based Vocabulary Learning System Based on } \\
\text { Multi-Agent System } \\
\text { by Preecha Tangworakitthaworn, Preeyapol Owatsuwan, } \\
\text { Nutsima Nongyai and Nongnapas Arayapong }\end{array}$ & 318 \\
\hline 1570542924 & $\begin{array}{l}\text { Software Defect Detection Based On Selected Complexity Met- } \\
\text { rics Using Fuzzy Association Rule Mining and Defective Mod- } \\
\text { ule Oversampling } \\
\text { by Mohammad Naufal and Selvia Kusuma }\end{array}$ & 324 \\
\hline 1570546325 & $\begin{array}{l}\text { Automatic Question Generation With Classification Based On } \\
\text { Mind Map } \\
\text { by Selvia Ferdiana Kusuma, Daniel Oranova Siahaan, } \\
\text { Chastine Fatichah and Mohammad Farid Naufal }\end{array}$ & 330 \\
\hline 1570547008 & $\begin{array}{l}\text { User Story Extraction from Online News for Software Re- } \\
\text { quirements Elicitation: A Conceptual Model } \\
\text { by Indra Kharisma Raharjana, Daniel Siahaan and } \\
\text { Chastine Fatichah }\end{array}$ & 336 \\
\hline
\end{tabular}




\section{Paper ID Title Page}

1570547291 Sequence Diagram Similarity Measurement: A Different Ap- 342 proach

by Evi Triandini, Reza Fauzan, Daniel O Siahaan and Siti Rochimah

1570537935 A Classification for Patients with Heart Disease Based on Ho- 346 effding Tree

by Sattarpoom Thaiparnit, Sorratha Kritsanasung and

Narumol Chumuang

1570541402 The Method of Integrating Virtual Reality with Brainwave

by Erdhi Widyarto Nugroho and Bernardinus Harnadi

1570543027 Impacts of Camera Frame Pacing for Video Recording on Time-Related Applications

by Nattapong Tangjui and Pinyo Taeprasartsit

1570543053 IoT-based Seven Segment Display Reader with Chessboard

Calibration and Template Determination

by Wansuree Massagram and Thanathorn Phoka

1570543059 Feature Reduction from Correlation Matrix for Classification of Two Basil Species in Common Genus

by Varin Chouvatut and Supawit Wattanapairotrat

1570547314 Eye-Tracking Based Visualizations and Metrics Analysis for Individual Eye Movement Patterns

by Rasa Bhattarai and Montri Phothisonothai

1570547322 Implementation the SoC of PCB Reflow Soldering

by Thanat Sooknuan 